\title{
Processing of Canned Mango using Natural Preservatives: Effect on the Physicochemical Characteristics and Hygien- ic Quality
}

\author{
Pingdwindé Marie Judith Samadoulougou-Kafando ${ }^{1,2}$, Hagrétou Sawadogo-Lingani ${ }^{*}$, Donatien \\ Kaboré1, Hyacinthe Kanté-Traoré1, Diarra Compaoré-Sérémé1 and Mamoudou Hama Dicko²
}

${ }^{1}$ Département Technologie Alimentaire/ Institut de Recherches en Sciences Appliquées et Technologies/ Centre National de la Recherche Scientifique et Tech-
nologique (DTA/IRSAT/CNRST), 03 BP 7047 Ouagadougou 03, Burkina Faso.
${ }^{2}$ Laboratoire de Biochimie, Biotechnologie, Technologie Alimentaire et Nutrition (LABIOTAN) Université Ouaga I Pr Joseph Ki-Zerbo, 09 BP 848 Ouagadougou 09, Burkina

*Corresponding author: Hagrétou Sawadogo-Lingani, Département Technologie Alimentaire (DTA/IRSAT/CNRST), 03 BP 7047 Ouagadougou 03, Ouagadougou, Burkina Faso, Tel : +226 72340096 ; Email kaftourb@yahoo.fr

\begin{abstract}
Optima preservation conditions to produce canned mangoes from three cultivars (Lippens, Kent and Keitt) were determined using lemon juice and lemongrass essential oils as natural preservatives and citric acid. Fresh mango pulp and canned mangoes were analyzed for physicochemical, microbiological and sensorial properties in order to assess the impact of the canning process. Depending on cultivars fresh mango pulp contained 437.5 to $3478.09 \mu \mathrm{g} / 100 \mathrm{~g}$ (dry matters) of beta-carotene. Total sugars, ash, titratable acidity, total soluble solids and $\mathrm{pH}$ were ranging between $49.29-67.25 \%$, 1.23-3.0 \%, 2.43-3.65\%, 17 - 18 and 3.40-3.80, respectively. Total mesophilic flora, total coliforms, yeasts and moulds counts of fresh pulp ranged from 1.8103 - $2.5104 \mathrm{CFU} / \mathrm{g}, 3.6101-1.6104$ and lest than 10 - $9.1101 \mathrm{CFU} / \mathrm{g}$, respectively. After processing of canned mangoes in sucrose syrup, levels of components changed from $320.04-1954.01 \mu \mathrm{g} / 100 \mathrm{~g}$ for beta-carotene, 50.65-79.01\% for total sugars, $0.3-1.06 \%$ for ash, $0.64-2.28 \%$ for titratable acidity and $23-32$ Brix for total soluble solids. The $\mathrm{pH}$ values oscillated between 3.19 and 3.98. More than $99.98 \%$ of total mesophilic flora was destroyed; no coliforms and no yeasts and moulds were detected in the canned mangoes.

From these results, the best preservatives were citric acid and lemongrass essential oil and the best pasteurization time is $10 \mathrm{~min}$.
\end{abstract}

Keywords: Mangifera indica; Canned mangoes; Natural preservative; Nutritional and hygienic quality; Burkina faso

\section{Introduction}

Mangifera indica L. (mango) is the main fruit in Burkina Faso accounting for an annual production of about 404000 tons (PAFASP, 2015) ${ }^{[1]}$. Cultivate area for mango trees represented about $58 \%$ of the area of the national orchard (Diallo, 2010). While $20 \%$ of this production is locally processed, only $5 \%$ of fresh mangoes are exported (DGPER, 2011) ${ }^{[2]}$. Thus, mango processing is poorly diversified and is mainly in the forms of drying and nectar production. In 2011, 80\% of mangoes processed in Burkina Faso is dried mainly for exportation (DGPER, 2011) ${ }^{[2]}$. Industrial processing of mango beverages is developed with semi-industrial and artisanal units processing juice/nectar and a fruit processing unit (DAFANI SA) with an average mango

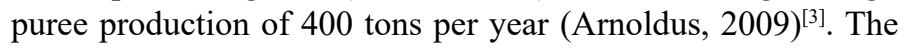
remaining of the production is used for local consumption. However, mango being a climacteric fruit, it is hardly conservable, causing important post-harvest losses according to environmental conditions. The lack of adequate post-harvest techniques and the low level of processing cause losses that can often reach 40 to $50 \%$ of the production (ECOWAS, 2011). Since freezing of mango fruits is not applicable, their shelf life after harvesting is between 8 to 12 days at room temperature and approximatively 25 days when stored at $8-12^{\circ} \mathrm{C}$ (Campbell et al., 1983; CBI, $2014)^{[4,5]}$. Canning will add value and also increase the availability of mango based products to contribute for over year food security. According to the CODEX STAN 159-1987 [5] "Canned mango is the product: (a) prepared from stemmed, peeled, fresh, sound, clean and mature fruit of commercial varieties conform-

\section{Received date: March 09, 2018 \\ Accepted Date: May 14, 2018 \\ Published Date: May 18, 2018}

Citation: Sawadogo-Lingani, H., et al. Processing of Canned Mango using Natural Preservatives: Effect on the Physicochemical Characteristics and Hygienic Quality. (2018) Int J Food Nutr Sci 5(1): 38- 46 .

Copyright: (C) 2018 Sawadogo-Lingani, H. This is an Open access article distributed under the terms of Creative Commons Attribution 4.0 International License. 
ing to the characteristics of the fruits of Mangifera indica L.; (b) which may or may not be packed with a suitable liquid packing medium, nutritive sweeteners and other seasoning or flavoring ingredients appropriate to the product; and (c) processed by heat, in an appropriate manner, before or after being sealed in a container, in order to preserve its essential composition and quality factors." However, in order to ensure good preservation of the final product, some processing methods use inadequate heat treatments causing the alteration of nutritional and organoleptic qualities of foods (Couvert, 2002) (7] $^{[7}$ Other methods employing chemical additives cause some adverse reactions including allergenicity (Bourrier, 2006) ${ }^{[8]}$. The involvement of certain chemical preservatives in the outbreak of some diseases justifies the development of products with natural preservatives. For instance, the effectiveness of essential oils as natural preservatives in food has been assessed in several studies (Romeo et al. 2010; Hyldgaard et al. 2012; Witkowska et al. 2014) $)^{[9-11]}$. Indeed, essential oils were found to express antioxidant and antimicrobial properties against a numerous microorganisms (Bassolé et al. 2011; Helander et al. 1998 $)^{[12,13]}$. Several data also show that lemon juice is a natural preservative with antioxidant and acidifying properties for food preservation (Agassounon et al. 2007) ${ }^{[14]}$. Due to consumer increasing demand for natural products, the use of natural additives in food processing is an alternative to obtain natural products with long shelf life. It is therefore necessary to develop a technological process using natural preservatives to satisfy consumers, to diversify mango products and to reduce losses. This contribution uses natural preservatives and short time heat treatment to improve process and preservation of canned mangoes in syrup.

\section{Materials and Methods}

\section{Mangoes used as raw materials}

Mangoes fruits from the cultivars Lippens, Kent and Keitt from Orodara, in the Western area of Burkina Faso (geographical coordinates: $11^{\circ} 11^{\prime} 00^{\prime}$ ' $\mathrm{N}$ and $4^{\circ} 17^{\prime} 00^{\prime \prime} \mathrm{W}$; $11.183333^{\circ}$, $-4.283333^{\circ}$ ) were used as raw materials in the present study. Mature mango fruits were picked separately from cultivars of 100 Lippens, 150 Kent and 150 Keitt. Mangoes of each cultivar were picked from the same orchard. Samples were conditioned by cultivar in cardboard boxes and transported by car to the laboratory.

\section{Preservative compounds}

Lemon (Citrus lemon) and sucrose were bought at Zogona market in Ouagadougou, Burkina Faso. Lemongrass essential oil (LEO) was provided by the Department of Natural Substances (DSN) of IRSAT/CNRST. Citric acid was purchased from COPROCHIM laboratory.

\section{Processing of canned mangoes}

The technology used was based on the general fruit canning diagram (BIT, 1990) ${ }^{[15]}$. Series of preliminary tests have been carried out in order to adapt the diagram to process of canned mangoes using natural preservatives. A test one was based on $\mathrm{pH}$ measurement with series of citric acid concentrations of e.g. $0.1 \%, 0.2 \%, 0.3 \%$, and $0.4 \%$ in sucrose syrup. A test two was based on $\mathrm{pH}$ measurement with series of lemon juice concen- trations of $0.3 \%, 0.5 \%, 0.8 \%, 1.0 \%, 1.3 \%, 1.5 \%$ and $1.8 \%$ in sucrose syrup. A sensory test (taste and aroma) with a concentration series of lemongrass essential oil of $0.001 \%, 0.002 \%$, $0.003 \%$ and $0.004 \%$ in the syrup allowed retaining the appropriate lemongrass essential oil concentration. As for the steam bleaching, a bleaching test, carried out at different times (2, 3, 4 and $5 \mathrm{~min}$ ) was used to select the appropriate bleaching time. The syrup is prepared with sucrose and water at dry matter level of 40 brix. Pasteurization was carried up in boiling water using appropriate equipment for different times (5, 10 and $15 \mathrm{~min}$ ).

The figure 1 shows the diagram of canned mangoes processing using natural preservatives. Mangoes fruits were ripened at room temperature for $4-16$ days. For that mature mangoes of each cultivar (Lippens, Kent and Keitt) were sorted, washed, peeled, pitted and cut into dice shape (mean side : 25-30 $\mathrm{mm}$ ). The cutted mango pulp was bleached at $99^{\circ} \mathrm{C}$ for $3 \mathrm{~min}$. Then $250 \mathrm{~g}$ of pulp were packed in twice off glass jar (capacity: $450 \mathrm{ml}$ ) previously washed and decontaminated by boiling in water for $15 \mathrm{~min}$. Hot sucrose syrup $\left(80-85^{\circ} \mathrm{C}\right)$ at the concentration of 40 Brix was added to each jar as covering liquid. For each cultivar, four types of canned mangoes were obtained according to the composition of the syrup: canned mangoes containing syrup with citric acid at $0.3 \% \mathrm{w} / \mathrm{v}$, canned mangoes containing syrup with lemon juice at $1 \% \mathrm{v} / \mathrm{v}$, canned mangoes containing syrup with lemongrass essential oil at $0.002 \% \mathrm{v} / \mathrm{v}$ and control canned mangoes in syrup without any preservative compound. The jars were closed and then each batch was divided into three groups for the pasteurization according to the time e.g. 5, 10 and 15 min. For canned mangoes of the Lippens cultivar, pasteurization times were 15 and $10 \mathrm{~min}$. In total, 32 different samples of canned mangoes were manufactured. The samples of canned mangoes were stored for 7 days at room temperature for stabilization before analyses.

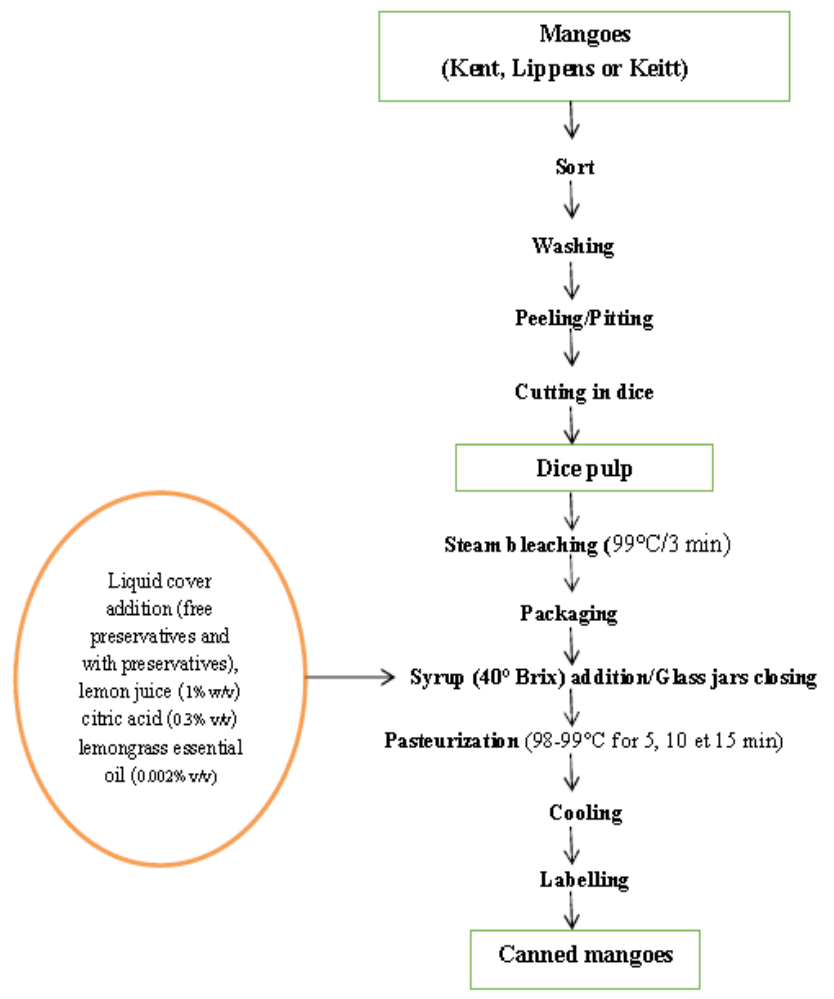

Figure 1: Diagram of canned mangoes processing using natural preservatives 
Citation: Sawadogo-Lingani, H., et al. Processing of Canned Mango using Natural Preservatives: Effect on the Physicochemical Characteristics and Hygienic Quality. (2018) Int J Food Nutr Sci 5(1): 38- 46.

Mangoes used as raw materials: Mangoes fruits from the cultivars Lippens, Kent and Keitt from Orodara, in the Western area were used as raw materials in the present study. Mature mango fruits were picked separately from cultivars of 100 Lippens, 150 Kent and 150 Keitt. Mangoes of each cultivar were picked from the same orchard. Samples were conditioned by cultivar in cardboard boxes and transported by car to the laboratory.

\section{Physicochemical analyses sample preparation}

Physicochemical analyses were performed on the pulp of fresh mangoes (3 samples) and on canned mangoes (32 samples) of the three mango cultivars. The pulps of fresh mangoes were ground in Blender Moulinex brand. Prior to analysis ground products $(200 \mathrm{~g})$ were packaged into sampling plastics jars and frozen at $20^{\circ} \mathrm{C}$. As for canned mangoes, they were first drained using a 0.5 $\mathrm{mm}$ sieve to separate mango pieces from syrup. The pulp was then ground using waring blender (Moulinex). Ground product $(200 \mathrm{~g})$ and the syrup $(150 \mathrm{~g})$ were packed in the sampling plastics jars and frozen at $-20^{\circ} \mathrm{C}$ before analysis. The syrup and the ground product were separately analyzed.

\section{Composite analysis}

The dry matter (DM) was determined by difference of sample weight before and after drying at $105 \pm 2{ }^{\circ} \mathrm{C}$ for $24 \mathrm{~h}$ (NF V03$707,2000)^{[16]}$. Results are expressed in percentage of fresh weight (FW). The total sugar was determined by sulfuric orcinol method as described by Montreuil and Spik (1969) ${ }^{[17]}$. It is a spectrophotometric method consisting of carbohydrates acid hydrolysis, intra-molecular dehydration of oses into fufurals and condensation of furfurals with phenols to obtained colored hemi- acetals or acetals. Results are expressed in percentage of dry weight (DW). Ash content was determined by incineration at $550^{\circ} \mathrm{C}$ for $12 \mathrm{~h}$ according to standard procedure (IS0 2171, 2007). The titratable acidity was determined according to AFNOR, standard method NF V05-101 (1986) ${ }^{[18]}$. The $\mathrm{pH}$ was measured by homogenizing $5 \mathrm{~g}$ of product in $25 \mathrm{ml}$ of distilled water using an electronic $\mathrm{pH}$ meter (CONSORT P901, Belgium). The titratable acidity was expressed by citric acid equivalents by titration with $0.1 \mathrm{~N} \mathrm{NaOH}$ using phenolphthalein as indicator. The total soluble solid was measured using an Euromex refractometer (IFFJFP, 12001).

The $\beta$-Carotene content of mango pulp and canned mango was assessed by high performance liquid chromatography as described by Somé et al. (2004) ${ }^{[19]}$. The external standard solution for calibration was prepared by mixing various quantity of $\beta$-carotene standard. Optical densities of eluted compounds were read at $450 \mathrm{~nm}$. The concentration of the solution having an optical density between 0.1 and 0.9 was calculated. From these standard solutions whose concentrations have been determined accurately, precise volume was taken to obtain a final solution of $60 \mathrm{pmol}$ in $20 \mu \mathrm{L}$. The $\beta$-carotene was extracted in mango sample with successive vortexing of $1 \mathrm{~g}$ of ground mango product for $2 \mathrm{~min}$ with $1 \mathrm{ml}$ of extraction solvent consisting of heterogenous mixture of hexane/3M sodium chloride/ethanol (1/1/1). After vigorous stirring, the mixture was centrifuged at 3000 $\mathrm{rpm}-1$ at $-5^{\circ} \mathrm{C}$, for $5 \mathrm{~min}$. This process was repeated three times. The hexanic phases were then pooled. The extract $(1 \mathrm{ml})$ was evaporated under a stream of nitrogen. The obtained residue was re-dissolved in $1 \mathrm{ml}$ of acetonitrile. After micro-filtration $(0.5 \mu \mathrm{m}$
Millipore membrane) the sample was injected in a LC-18 Supelcosil column (Bellefonte, USA), with $25 \mathrm{~cm}$ in length, and $4.6 \mathrm{~mm}$ in diameter using a loop of $20 \mu \mathrm{l}$. The mobile phase was a mixture of acetonitrile, dichloromethane and methanol in of proportions of $7 / 2 / 1$, respectively. The elution was in an isocratic mode. During the elution, carotenoids were identified by their retention time of $6.22 \mathrm{~min} \pm 0.26$ compared to external standards using a Jasco UV 975 detector (Tokyo, Japon), online interfaced with a computer with an operating Software Galaxie workstation version 1.9.3.2. Results are expressed in micrograms of $\beta$-carotene to $100 \mathrm{~g}$ of dry matter.

\section{Microbiological analyses}

Total microflora was quantified according to ISO 6887 (1999) ${ }^{[20]}$. Roughly $10 \mathrm{~g}$ of the samples were homogenized in a stomacher with $90 \mathrm{ml}$ of sterile peptoned buffered water. Tenfold serial dilutions were prepared and appropriates dilutions were spread-plated for microorganisms counts. Aerobic mesophilic bacteria (AMB) were counted by cultivation on plate agar count (Liofilchem, Italy) after incubation at $30^{\circ} \mathrm{C}$ for 72 hours according to ISO 4833 (2006). Total coliforms were determined by cultivation on violet red bile lactose agar (Liofilchem, Italy)

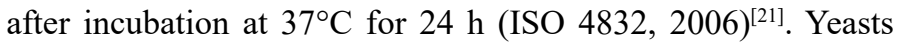
and moulds were counted by cultivation on Sabouraud- chloramphenicol agar (Liofilchem, Italy) after incubation at $25^{\circ} \mathrm{C}$ for 4-5 days (ISO 7954, 1988) ${ }^{[22]}$. Results are expressed in CFU per gram of sample.

\section{Sensorial analyses}

Sensorial assays were conducted according to the ISO 11035 $(1994)^{[23]}$. The evaluation concerned sensory attributes and sample acceptability. Tests were performed at the sensory laboratory of the Institute of Applied Sciences and Technologies, CNRST, Burkina Faso. Tasters had a level of education at least for secondary school. Four tests were performed on canned mango: i) 9 tasters for sensory attributes such as appearance, aroma and texture of the pieces of mango pulp and the appearance of the syrup was tested; ii) 34 tasters evaluated the acceptability according to the preservative; iii) 24 tasters evaluated the acceptability according to the duration of pasteurization; and the last iv) 24 tasters evaluated the acceptability according to the mango cultivars. The canned mangoes of each formulation were randomly placed in codified plates with three-digit code (Cochran W.G, 1957) ${ }^{[24]}$ and served to each panelist. Sensory evaluation was based on comparative team tasting approach used in companies where some basic rules are followed for a rigorous evaluation protocol, blind evaluation, sample quality control, individual evaluation without interaction with the team, controlled order of sample tasting, controlled tasting condition and protocol monitoring (Rogeaux, 2015) ${ }^{[25]}$.

\section{Statistical analyses}

All the physicochemical analyses were performed in triplicate. Simple statistic analysis was used to get means and standard deviations. Data obtained were submitted to analysis of variance (ANOVA) and comparisons were made by Tukey's method ( $\mathrm{P}=$ 0.05) using XLSTAT, version 7.5.2. Sensorial analysis was submitted interpreted using SPSS 20 software (Statitics.V2 $\times 86 \times$ 
64 multilingual EQUINOX).

\section{Results}

\section{Nutritional, physicochemical and microbiological properties of raw mango}

Data with respect to nutritional and physicochemical characteristics of fresh mangoes from the three cultivars (Kent, Keitt and Lippens) are recorded in tables 1 and 2. Mango pulp contained $17.43-20.15 \%$ of dry matter, $49.29-67.25 \%$ (DW) for total sugars, $1.23-3.00 \%$ (DW) of ash and $437.52-3478.09 \mu \mathrm{g} / 100 \mathrm{~g}$ (DW) for beta-carotene. As for the physicochemical characteristics, titratable acidity, total soluble solids and $\mathrm{pH}$ were 2.43 - 3.65\% (DW); 17 - 18 and $3.40-3.80$, respectively. For the three cultivars, variability was observed between the levels of different compounds and especially between ash and $\beta$-carotene contents. The cultivar Kent contained the highest values of ash $[3.00 \%(\mathrm{DW})]$, total sugars $[67.25(\mathrm{DW})]$ and $\beta$-carotene $[3478.09 \mu \mathrm{g} / 100 \mathrm{~g}$ (DW) $]$ and can be considered as the best cultivar at the nutritional point of view as shown in the principal component analysis figure (figure 2).

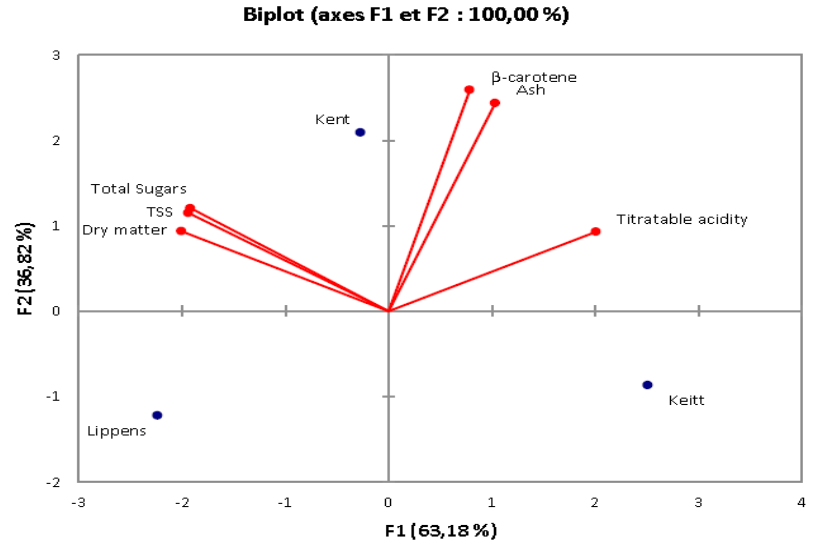

Figure 2: Principal component analysis of nutritional characteristic of raw material

Table 1: Nutritional characteristics of fresh mangoes pulp

\begin{tabular}{|l|l|l|l|l|}
\hline $\begin{array}{l}\text { Mango } \\
\text { cultivar }\end{array}$ & $\begin{array}{l}\text { Dry matter } \\
(\mathrm{g} / 100 \mathrm{~g} \text { FW })\end{array}$ & $\begin{array}{l}\text { Ash }(\mathrm{g} / 100 \mathrm{~g} \\
\mathrm{DW})\end{array}$ & $\begin{array}{l}\text { Total Sugars } \\
(\mathrm{g} / 100 \mathrm{~g} \text { DW })\end{array}$ & $\begin{array}{l}\beta-\mathrm{c} \text { a r o t e n e } \\
(\mu \mathrm{g} / 100 \mathrm{~g} \text { DW })\end{array}$ \\
\hline Lippens & $20.15 \pm 0.06^{\mathrm{a}}$ & $1.23 \pm 0.01^{\mathrm{c}}$ & $66.80 \pm 0.64^{\mathrm{a}}$ & $437.52 \pm 67.01^{\mathrm{c}}$ \\
\hline Kent & $19.90 \pm 0.03^{\mathrm{a}}$ & $3.00 \pm 0.09^{\mathrm{a}}$ & $67.25 \pm 1.29^{\mathrm{a}}$ & $3478.09 \pm 369.79^{\mathrm{a}}$ \\
\hline Keitt & $17.43 \pm 0.59^{\mathrm{b}}$ & $2.24 \pm 0.00^{\mathrm{b}}$ & $49.29 \pm 0.65^{\mathrm{b}}$ & $1833.51 \pm 31.59^{\mathrm{b}}$ \\
\hline
\end{tabular}

Means followed by the same letter in a column are not significantly different (Tukey's test. $P<0.05$ )

Table 2: Physicochemical characteristics of fresh mangoes pulp

\begin{tabular}{|l|l|l|l|}
\hline Mango cultivar & $\begin{array}{l}\text { Titratable acidity } \\
(\mathrm{g} / 100 \mathrm{~g} \text { DW })\end{array}$ & $\begin{array}{l}\text { Total soluble } \\
\text { solids }\end{array}$ \\
\hline Lippens & $2.43 \pm 0.02 \mathrm{c}$ & $3.80 \pm 0.01 \mathrm{a}$ & $18 \pm 0.00 \mathrm{a}$ \\
\hline Kent & $3.30 \pm 0.04 \mathrm{~b}$ & $3.40 \pm 0.02 \mathrm{c}$ & $18 \pm 0.00 \mathrm{a}$ \\
\hline Keitt & $3.65 \pm 0.02 \mathrm{a}$ & $3.53 \pm 0.04 \mathrm{~b}$ & $17 \pm 0.00 \mathrm{~b}$ \\
\hline
\end{tabular}

Means followed by the same letter in a column are not significantly different (Tukey's test. $P<0.05$ )

As for the microbiological characteristic, the total mesophilic bacteria in the fresh pulp of the three cultivars of mango ranged from $1.8 \times 103 \mathrm{CFU} / \mathrm{g}$ to $2.5 \times 104 \mathrm{CFU} / \mathrm{g}$, the total coliforms ranged from $40 \mathrm{CFU} / \mathrm{g}$ to $1.6 \times 104 \mathrm{CFU} / \mathrm{g}$ and yeasts and moulds, from less than $10 \mathrm{CFU} / \mathrm{g}$ to $9.1 \times 101 \mathrm{CFU} / \mathrm{g}$.

\section{Nutritional and physicochemical characteristics of canned mangoes}

Nutritional and physicochemical characteristics of canned mangoes are presented in the tables 3 to 8 . For Lippens cultivars dry matter content, total sugar and ash (table 3 ) varied from $28.19 \%$ to $32.71 \%$ (FW) with a mean value of $30.83 \%$ (FW), from 54.16 $\%$ to $66.30 \%(\mathrm{DW})$ with a mean value of $58.44 \%(\mathrm{DW})$ and $0.32 \%$ to $0.62 \%$ (DW) with a mean value of $0.46 \%$ (DW), respectively. Concerning the total soluble solids, titratable acidity and $\mathrm{pH}$ (table 4), the values varied from 26.00 to 29.53 oBrix with a mean value of $27.27 \mathrm{oBrix}$, from $0.64 \%$ to $1.69 \%$ (DW) with a mean value of $1.03 \%$ (DW) and from 3.26 to 3.90 with a mean value of 3.68 , respectively.

Table 3: Nutritional characteristics of Lippens canned mangoes.

\begin{tabular}{|l|l|l|l|l|}
\hline $\begin{array}{l}\text { Pasteuriza- } \\
\text { tion scales }\end{array}$ & $\begin{array}{l}\text { Preser- } \\
\text { vatives }\end{array}$ & $\begin{array}{l}\text { Dry matter } \\
(\mathrm{g} / 100 \mathrm{~g} \mathrm{FW})\end{array}$ & $\begin{array}{l}\text { Ash }(\mathrm{g} / 100 \mathrm{~g} \\
\mathrm{DW})\end{array}$ & $\begin{array}{l}\text { Total Sugars } \\
(\mathrm{g} / 100 \mathrm{~g} \mathrm{DW})\end{array}$ \\
\hline $\begin{array}{l}98-99^{\circ} \mathrm{C} / 15 \\
\text { min }\end{array}$ & $\begin{array}{l}\text { Con- } \\
\text { trol }\end{array}$ & $29.38 \pm 0.46^{\mathrm{d}}$ & $0.5 \pm 0.01^{\mathrm{bc}}$ & $54.92 \pm 0.87^{\mathrm{a}}$ \\
\cline { 2 - 5 } & $\begin{array}{l}\text { Lemon } \\
\text { juice }\end{array}$ & $32.67 \pm 0.18^{\mathrm{a}}$ & $0.32 \pm 0.01^{\mathrm{f}}$ & $66.30 \pm 0.30^{\mathrm{a}}$ \\
\cline { 2 - 5 } & $\begin{array}{l}\text { Citric } \\
\text { acid }\end{array}$ & $31.97 \pm 0.51^{\mathrm{a}}$ & $0.39 \pm 0.01^{\mathrm{e}}$ & $56.95 \pm 0.61^{\mathrm{a}}$ \\
\cline { 2 - 5 } & सEO $^{\mathrm{L}}$ & $28.19 \pm 0.09^{\mathrm{e}}$ & $0.62 \pm 0.00^{\mathrm{a}}$ & $64.98 \pm 0.54^{\mathrm{a}}$ \\
\hline \multirow{2}{*}{$\begin{array}{l}98-99^{\circ} \mathrm{C} / 10 \\
\text { min }\end{array}$} & $\begin{array}{l}\text { Con- } \\
\text { trol }\end{array}$ & $30.72 \pm 0.01^{\mathrm{bc}}$ & $0.38 \pm 0.01^{\mathrm{e}}$ & $55.66 \pm 0.50^{\mathrm{a}}$ \\
\cline { 2 - 5 } & $\begin{array}{l}\text { Lemon } \\
\text { juice }\end{array}$ & $30.05 \pm 0.07^{\mathrm{cd}}$ & $0.53 \pm 0.00^{\mathrm{b}}$ & $54.16 \pm 1.59^{\mathrm{a}}$ \\
\cline { 2 - 5 } & $\begin{array}{l}\text { Citric } \\
\text { acid }\end{array}$ & $30.91 \pm 0.11^{\mathrm{b}}$ & $0.47 \pm 0.01^{\mathrm{d}}$ & $59.97 \pm 2.67^{\mathrm{a}}$ \\
\cline { 2 - 5 } & LEO & $32.71 \pm 0.33^{\mathrm{a}}$ & $0.48 \pm 0.01^{\mathrm{cd}}$ & $54.62 \pm 2.15^{\mathrm{a}}$ \\
\hline
\end{tabular}

*LEO: Lemongrass essential oil. Means followed by the same letter in a column are not significantly different (Tukey's test. $P<0.05$ ).

Table 4: Physicochemical characteristics of Lippens canned mangoes

\begin{tabular}{|c|c|c|c|c|}
\hline $\begin{array}{l}\text { Pasteuriza- } \\
\text { tion scales }\end{array}$ & $\begin{array}{l}\text { Preser- } \\
\text { vatives }\end{array}$ & $\begin{array}{l}\text { Titrable acidity } \\
\text { (g/100g DW) }\end{array}$ & $\mathrm{pH}$ & $\begin{array}{l}\text { Total solu- } \\
\text { ble solids }\end{array}$ \\
\hline \multirow{4}{*}{$\begin{array}{l}9 \quad 8 \quad- \\
99^{\circ} \mathrm{C} / 15 \\
\min \end{array}$} & Control & $1.00 \pm 0.14^{\mathrm{bc}}$ & $3.89 \pm 0.02^{\mathrm{a}}$ & $\begin{array}{l}29.53 \\
0.12^{\mathrm{a}}\end{array}$ \\
\hline & $\begin{array}{l}\text { Lemon } \\
\text { juice }\end{array}$ & $0.87 \pm 0.10 b^{\mathrm{cd}}$ & $3.68 \pm 0.06^{\mathrm{bc}}$ & $26.6 \pm 0.00^{\mathrm{e}}$ \\
\hline & $\begin{array}{l}\text { Citric } \\
\text { acid }\end{array}$ & $1.13 \pm 0.07^{\mathrm{b}}$ & $3.43 \pm 0.03^{\mathrm{d}}$ & $28.2 \pm 0.12^{\mathrm{b}}$ \\
\hline & $*$ LEO & $1.08 \pm 0.14^{\mathrm{bc}}$ & $3.9 \pm 0.02^{\mathrm{a}}$ & $26.6 \pm 0.12^{\mathrm{f}}$ \\
\hline \multirow{4}{*}{$\begin{array}{l}9 \quad 8 \quad- \\
99^{\circ} \mathrm{C} / 10 \\
\min \end{array}$} & Control & $0.80 \pm 0.08^{e}$ & $3.78 \pm 0.02^{\mathrm{b}}$ & $26 \pm 0.00^{\mathrm{g}}$ \\
\hline & $\begin{array}{l}\text { Lemon } \\
\text { juice }\end{array}$ & $1.02 \pm 0.03^{\mathrm{bc}}$ & $3.73 \pm 0.05^{\mathrm{b}}$ & $26.6 \pm 0.00^{\mathrm{e}}$ \\
\hline & $\begin{array}{l}\text { Citric } \\
\text { acid }\end{array}$ & $1.69 \pm 0.06^{\mathrm{a}}$ & $3.26 \pm 0.01^{\mathrm{e}}$ & $27.7 \pm 0.00^{\mathrm{c}}$ \\
\hline & LEO & $0.64 \pm 0.06^{\mathrm{d}}$ & $3.79 \pm 0.04^{b}$ & $26.9 \pm 0.12^{\mathrm{d}}$ \\
\hline
\end{tabular}

*LEO: Lemongrass essential oil. Means followed by the same letter in a column are not significantly different (Tukey's test. $P<0.05$ ) 
Citation: Sawadogo-Lingani, H., et al. Processing of Canned Mango using Natural Preservatives: Effect on the Physicochemical Characteristics and Hygienic Quality. (2018) Int J Food Nutr Sci 5(1): 38- 46.

Nutritional and physicochemical characteristics of Kent canned mangoes are presented in the tables 5 and 6 respectively. The dry matter content, the total sugar and ash (table 5) varied from 28.51 to $34.72 \%(\mathrm{FW})$ with a mean value of $31.05 \%$ (FW), from 50.65 to $63.14 \%$ (DW) with a mean value of $58.00 \%$ (DW) and 0.51 to $0.69 \%$ (DW) with a mean value of $0.59 \%$ (DW), respectively. Concerning the total soluble solids, the titratable acidity and the $\mathrm{pH}$ (table 6 ) the value varied from 27.20 to 32.00 with a mean value of 29.53 , from 1.35 to $2.10 \%$ (DW) with a mean value of $1.62 \%$ (DW) and from 3.27 to 3.51 with a mean value of 3.38 , respectively.

Table 5: Nutritional characteristics of Kent canned mangoes

\begin{tabular}{|c|c|c|c|c|}
\hline $\begin{array}{l}\text { Pasteuriza- } \\
\text { tion Scales }\end{array}$ & $\begin{array}{l}\text { Preserva- } \\
\text { tives }\end{array}$ & $\begin{array}{l}\text { Dry matter } \\
(\mathrm{g} / 100 \mathrm{~g} F W)\end{array}$ & $\begin{array}{l}\text { Ash }(g / 100 g \\
\text { DW) }\end{array}$ & $\begin{array}{l}\text { Total Sugars } \\
(\mathrm{g} / 100 \mathrm{~g} D W)\end{array}$ \\
\hline \multirow{4}{*}{$\begin{array}{l}98-99^{\circ} \mathrm{C} / 15 \\
\min \end{array}$} & Control & $34.33 \pm 0.32^{\mathrm{a}}$ & $0.55 \pm 0.02^{\mathrm{de}}$ & $54.11 \pm .60^{\mathrm{a}}$ \\
\hline & Lemon juice & $34.72 \pm 0.15^{\mathrm{a}}$ & $0.59 \pm 0.03^{\mathrm{bcd}}$ & $55.43 \pm 1.31^{\mathrm{a}}$ \\
\hline & Citric acid & $34.49 \pm 0.47^{\mathrm{a}}$ & $0.63 \pm 0.03^{\mathrm{bc}}$ & $57.30 \pm 0.71^{\mathrm{a}}$ \\
\hline & *LEO & $33.36 \pm 0.19^{b}$ & $0.56 \pm 0.03^{\text {cd }}$ & $54.01 \pm 1.28^{\mathrm{a}}$ \\
\hline \multirow{4}{*}{$\begin{array}{l}98-99^{\circ} \mathrm{C} / 10 \\
\min \end{array}$} & Control & $28.51 \pm 0.61^{\mathrm{e}}$ & $0.64 \pm 0.03^{\text {bc }}$ & $60.02 \pm 1.18^{a}$ \\
\hline & Lemon juice & $30.33 \pm 0.10^{c}$ & $0.51 \pm 0.02^{\mathrm{e}}$ & $62.13 \pm 1.28^{a}$ \\
\hline & Citric acid & $29.31 \pm 0.08^{\text {de }}$ & $0.57 \pm 0.01^{\mathrm{cd}}$ & $59.08 \pm 0.85^{\mathrm{a}}$ \\
\hline & LEO & $29.39 \pm 0.25^{\mathrm{d}}$ & $0.53 \pm 0.01^{\mathrm{de}}$ & $50.65 \pm 1.01^{\mathrm{a}}$ \\
\hline \multirow{4}{*}{$\begin{array}{l}98-99^{\circ} \mathrm{C} / 5 \\
\min \end{array}$} & Control & $28.77 \pm 0.17^{\text {de }}$ & $0.67 \pm 0.02^{b}$ & $63.14 \pm 1.98^{\mathrm{a}}$ \\
\hline & Lemon juice & $29.15 \pm 0.21^{\text {de }}$ & $0.69 \pm 0.03 \mathrm{a}$ & $59.34 \pm 0.21^{\mathrm{a}}$ \\
\hline & Citric acid & $29.39 \pm 0.25^{\mathrm{d}}$ & $0.66 \pm 0.03^{\mathrm{bc}}$ & $57.68 \pm 0.81^{\mathrm{a}}$ \\
\hline & LEO & $30.88 \pm 0.21^{\mathrm{c}}$ & $0.53 \pm 0.01^{\mathrm{de}}$ & $63.07 \pm 1.46^{\mathrm{a}}$ \\
\hline
\end{tabular}

*LEO: Lemongrass essential oil. Means followed by the same letter in a column are not significantly different (Tukey's test. $\mathrm{P}<0.05$ )

Table 6: Physicochemical characteristics of Kent canned mangoes

\begin{tabular}{|c|c|c|c|c|}
\hline $\begin{array}{l}\text { Pasteuriza- } \\
\text { tion Scales }\end{array}$ & $\begin{array}{l}\text { Preserva- } \\
\text { tives }\end{array}$ & $\begin{array}{l}\text { Titratable acidi- } \\
\text { ty }(\mathrm{g} / 100 \mathrm{~g} \mathrm{DW})\end{array}$ & $\mathrm{pH}$ & $\begin{array}{l}\text { Total soluble } \\
\text { solids }\end{array}$ \\
\hline \multirow{4}{*}{$\begin{array}{l}98-99^{\circ} \mathrm{C} / 15 \\
\min \end{array}$} & Control & $1.35 \pm 0.02^{\mathrm{e}}$ & $3.35 \pm 0.02^{\mathrm{def}}$ & $30.80 \pm 0.00^{c}$ \\
\hline & $\begin{array}{l}\text { Lemon } \\
\text { juice }\end{array}$ & $1.50 \pm 0.05^{\text {cde }}$ & $3.33 \pm 0.00^{\mathrm{def}}$ & $32.00 \pm 0.00^{\mathrm{a}}$ \\
\hline & Citric acid & $1.67 \pm 0.05^{\mathrm{bcd}}$ & $3.3 \pm 0.00^{\mathrm{fg}}$ & $31.73 \pm 0.12^{b}$ \\
\hline & $*$ LEO & $1.45 \pm 0.02^{\mathrm{de}}$ & $3.37 \pm 0.00^{\text {cde }}$ & $29.67 \pm 0.12^{\mathrm{d}}$ \\
\hline \multirow{4}{*}{$\begin{array}{l}98-99^{\circ} \mathrm{C} / 10 \\
\min \end{array}$} & Control & $1.72 \pm 0.02^{\mathrm{bc}}$ & $3.51 \pm 0.08^{\mathrm{a}}$ & $28.73 \pm 0.12^{\mathrm{e}}$ \\
\hline & $\begin{array}{l}\text { Lemon } \\
\text { juice }\end{array}$ & $1.37 \pm 0.08^{\mathrm{e}}$ & $3.42 \pm 0.01^{\mathrm{bc}}$ & $27.33 \pm 0.12^{\mathrm{h}}$ \\
\hline & Citric acid & $1.79 \pm 0.05^{\mathrm{b}}$ & $3.32 \pm 0.03^{\text {ef }}$ & $28.00 \pm 0.00^{\mathrm{g}}$ \\
\hline & LEO & $1.47 \pm 0.07^{\mathrm{de}}$ & $3.45 \pm 0.01^{\mathrm{b}}$ & $30.93 \pm 0.12^{\mathrm{c}}$ \\
\hline \multirow{4}{*}{$\begin{array}{l}98-99^{\circ} \mathrm{C} / 5 \\
\min \end{array}$} & Control & $1.83 \pm 0.21^{\mathrm{b}}$ & $3.44 \pm 0.02^{\mathrm{b}}$ & $27.20 \pm 0.00^{\mathrm{h}}$ \\
\hline & $\begin{array}{l}\text { Lemon } \\
\text { juice }\end{array}$ & $1.86 \pm 0.08^{\mathrm{ab}}$ & $3.36 \pm 0.10^{\mathrm{de}}$ & $27.80 \pm 0.00^{\mathrm{g}}$ \\
\hline & Citric acid & $2.10 \pm 0.10^{\mathrm{a}}$ & $3.27 \pm 0.03^{\mathrm{g}}$ & $31.87 \pm 0.12^{\mathrm{ab}}$ \\
\hline & LEO & $1.35 \pm 0.03^{\mathrm{e}}$ & $28.33 \pm 0.12^{\mathrm{f}}$ & $28.33 \pm 0.12^{\mathrm{f}}$ \\
\hline
\end{tabular}

*LEO: Lemongrass essential oil; Means followed by the same letter in a column are not significantly different (Tukey's test. $\mathrm{P}<0.05$ )

Concerning Keitt canned mangoes, nutritional and physicochemical characteristics are presented in tables 7 and 8 , respectively. Dry matter content, total sugar and ash (table 7) varied from to $27.63 \%(\mathrm{FW})$ with a mean value of $24.46 \%$ (FW), from 62.31 to $79.01 \%$ (DW) with a mean value of $67.62 \%$ (DW) and from 0.62 to $1.06 \%$ (DW) with a mean value of $0.78 \%$
(DW) respectively.

Table 7: Nutritional characteristics and ash of Keitt canned mangoes

\begin{tabular}{|c|c|c|c|c|}
\hline $\begin{array}{l}\text { Pasteuriza- } \\
\text { tion scales }\end{array}$ & Preser & $\begin{array}{l}\text { Dry matter } \\
(\mathrm{g} / 100 \mathrm{~g} F W)\end{array}$ & $\begin{array}{l}\text { Ash }(g / 100 g \\
\text { DW) }\end{array}$ & $\begin{array}{l}\text { Total Sugars } \\
(\mathrm{g} / 100 \mathrm{~g} \text { DW) }\end{array}$ \\
\hline \multirow{4}{*}{$\begin{array}{l}98-99^{\circ} \mathrm{C} / 15 \\
\min \end{array}$} & 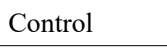 & $25.79 \pm 0.15^{\mathrm{ab}}$ & $0.72 \pm 0.01^{\text {def }}$ & $67.82 \pm 0.30^{\mathrm{bc}}$ \\
\hline & Lemon & $21.09 \pm 0.12^{\mathrm{e}}$ & $0.74 \pm 0.04^{\text {cde }}$ & $73.67 \pm 0.13^{\mathrm{bc}}$ \\
\hline & Citric & $23.69 \pm 0.26^{\mathrm{cd}}$ & $0.82 \pm 0.00^{c}$ & $64.71 \pm 0.49^{\text {cde }}$ \\
\hline & & $21.99 \pm 0.17^{\mathrm{de}}$ & $1.00-$ & $63.97 \pm 0.29^{\mathrm{de}}$ \\
\hline \multirow{4}{*}{$\begin{array}{l}98-99^{\circ} \mathrm{C} / 10 \\
\min \end{array}$} & Control & $22.70 \pm 0.13^{\mathrm{de}}$ & $0.94 \pm$ & $30.70+0.00$ \\
\hline & Lemo & $23.82 \pm$ & $0.87 \pm$ & $78.38 \pm 2.54^{b}$ \\
\hline & Citric & $24.68 \pm 0.07^{\mathrm{bc}}$ & $0.79 \pm 0.01^{\mathrm{cd}}$ & $65.84 \pm 0.41^{\mathrm{bcd}}$ \\
\hline & LEO & $25.83 \pm 0.28^{\mathrm{ab}}$ & $0.67 \pm 0.00^{\mathrm{fg}}$ & $67.32 \pm 0.46^{\mathrm{bc}}$ \\
\hline \multirow{4}{*}{$\begin{array}{l}98-99^{\circ} \mathrm{C} / 5 \\
\min \end{array}$} & Control & $27.63 \pm 0.14^{\mathrm{a}}$ & $0.71 \pm 0.00^{\text {def }}$ & $64.42 \pm 0.74^{\text {cde }}$ \\
\hline & Lemon & $27.14 \pm 0.23^{\mathrm{a}}$ & $0.73 \pm 0.00^{\text {cde }}$ & $65.04 \pm 0.05^{\text {cde }}$ \\
\hline & Citric acid & $22.22 \pm 0.02^{\mathrm{de}}$ & $0.68 \pm 0.03^{\mathrm{efg}}$ & $62.31 \pm 0.35^{\mathrm{de}}$ \\
\hline & LEO & $26.96 \pm 2.14^{\mathrm{a}}$ & $0.62 \pm 0.01^{\mathrm{g}}$ & $79.01 \pm 0.68^{\mathrm{a}}$ \\
\hline
\end{tabular}

*LEO: Lemongrass essential oil, Means followed by the same letter in a column are not significantly different (Tukey's test. $\mathrm{P}<0.05$ )

Concerning the total soluble solids, the content varied from 23.00 to 28.00 with a mean value 24.99 . The titratable acidity varied from 0.98 to $2.28 \%$ (DW) with a mean value of $1.56 \%$ (DW) and the $\mathrm{pH}$ values varied from 3.19 to 3.98 with a mean value 3.55 .

\section{Effect of canning process on $\beta$-carotene content of the canned mangoes}

Figures 3 show the $\beta$-carotene content in canned mangoes. Canned mangoes formulated with citric acid (KtA) gave the highest $\beta$-carotene content of $1434,61 \mu \mathrm{g} / 100 \mathrm{~g} \mathrm{DW}$, followed by canned mangoes containing lemongrass essential oil $(\mathrm{KtH})$ with $\beta$-carotene content of $916,88 \mu \mathrm{g} / 100 \mathrm{~g} \mathrm{DW}$ and the canned mangoes containing lemon juice (KtC) with the $\beta$-carotene content of $556,66 \mu \mathrm{g} / 100 \mathrm{~g}$ DW compared to the control canned mangoes (KtT) which does not contain any preservative, with $393,35 \mu \mathrm{g} / 100 \mathrm{~g}$ DW of $\beta$-carotene (Figure 3A).

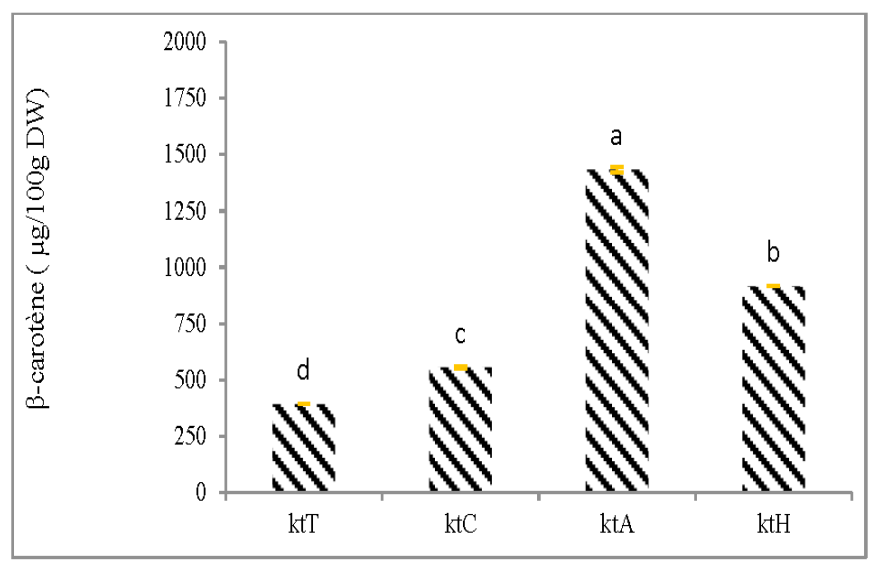

Figure 3: Effects of the preservatives, the pasteurization and the cultivar on $\beta$-carotene content of canned mangoes

Figure 3A: Effect of the preservatives on $\beta$-carotene content of canned mangoes (cultivar Keitt);

The (figure 3B) shows the influence of pasteurization time on $\beta$-carotene content in the Keitt cultivar canned mangoes. The highest rate of $\beta$-carotene (1954.01 $\mu \mathrm{g} / 100 \mathrm{~g} D W)$ was as- 
sociated with the pasteurization for $15 \mathrm{~min}(\mathrm{KtC} 15)$, followed by pasteurization for $10 \mathrm{~min}(\mathrm{KtCl})$, while the lowest rate $(556.66 \mu \mathrm{g} / 100 \mathrm{~g} \mathrm{DW})$ was observed with pasteurization for 5 $\min (\mathrm{KtC} 5)$.

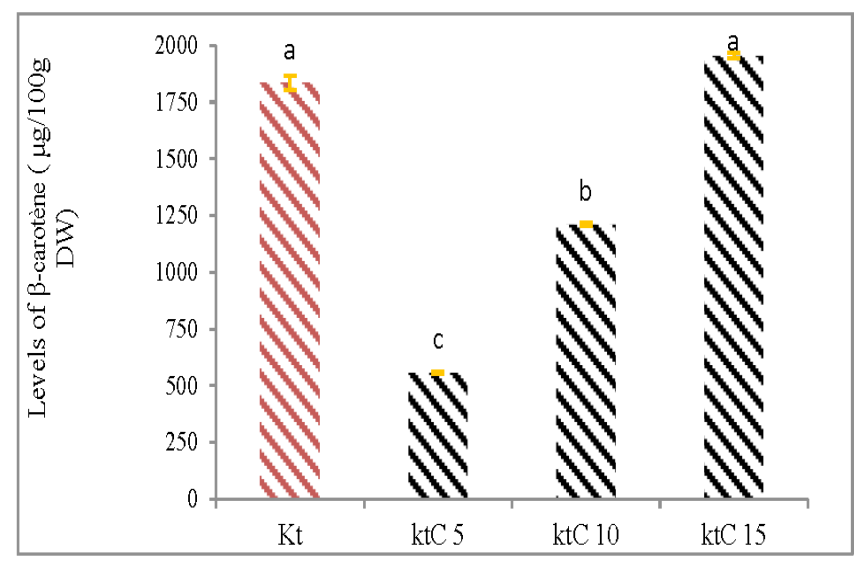

Figure 3B: Effect of the duration of the pasteurization on $\beta$-carotene content of canned mangoes (cultivar Keitt).

The (figure 3C) compares the $\beta$-carotene content in canned mango from the three cultivars of mango (Lippens, Kent and Keitt). The highest $\beta$-carotene content was obtained with the Kent cultivar using lemon juice $(1004.88 \mu \mathrm{g} / 100 \mathrm{~g}$ DW) or lemongrass essential oil $(929.17 \mu \mathrm{g} / 100 \mathrm{~g}$ DW). The lowest $\beta$-carotene content was observed with the Lippens cultivar using lemon juice $(320.04 \mu \mathrm{g} / 100 \mathrm{~g} \mathrm{DW})$ or lemongrass essential oil (465.40 $\mu \mathrm{g} / 100 \mathrm{~g} \mathrm{DW})$.

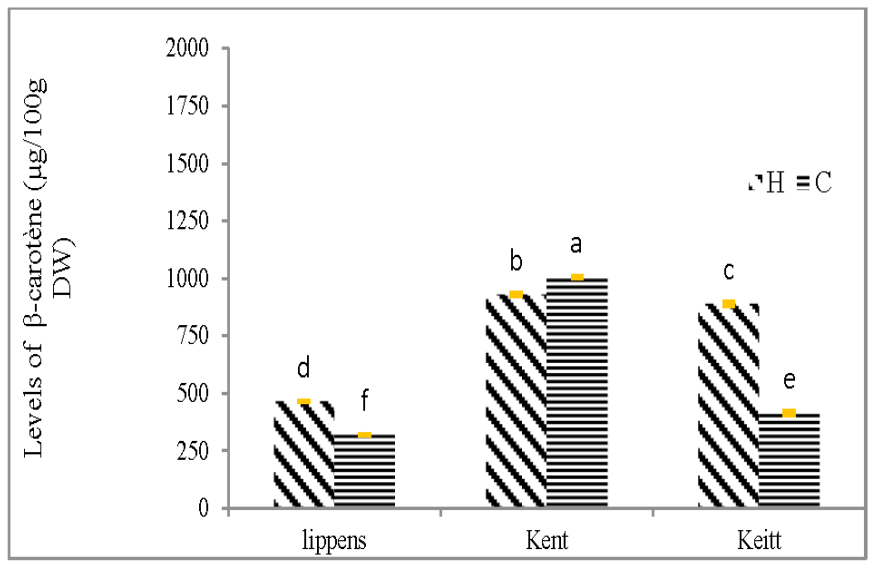

Figure 3C: $\beta$-carotene content of canned mangoes according three cultivars (Lippens, Kent and Keitt).

\section{Effect of canning process on the nutritional characteristic of the mango pulp}

After processing, the nutritional and physicochemical characteristics of fresh mango pulp changed. An increase in total dry matter, total sugars and total soluble solids was observed. The increase in dry matter content averaged 7.03 - 11.15\% (FW) according the cultivar. For total sugars content and total soluble solids, the average increase was $3.9-5.52 \%(\mathrm{FW})$ and 8.0 $11.5^{\circ}$ Brix respectively, depending on the cultivar.

There was a decrease of ash content in canned mango. The average decline was $44 \%$ for Lippens, $67 \%$ for Kent and $49 \%$ for Keitt. The cultivar Lippens exhibited a better retention of mineral salts compared to the other two cultivars. However, because of the high ash content of Kent and Keitt mangoes, the canned mangoes of these two cultivars had higher ash contents than the ash content of Lippens canned mangoes(table 8).

Table 8: Physicochemical characteristics of Keitt canned mangoes

\begin{tabular}{|c|c|c|c|c|}
\hline $\begin{array}{l}\text { Pasteuriza- } \\
\text { tion scales }\end{array}$ & $\begin{array}{l}\text { preserva- } \\
\text { tives }\end{array}$ & $\begin{array}{l}\text { Titrable acidity } \\
(\mathrm{g} / 100 \mathrm{~g} \text { DW) }\end{array}$ & $\mathrm{pH}$ & $\begin{array}{l}\text { Total soluble } \\
\text { solide }\end{array}$ \\
\hline \multirow{4}{*}{$\begin{array}{l}98-99^{\circ} \mathrm{C} / 15 \\
\min \end{array}$} & Control & $0.98 \pm 0.04 d$ & $3.52 \pm 0.02 \mathrm{c}$ & $23.7 \pm 0.12 \mathrm{~g}$ \\
\hline & Lemon juice & $2.28 \pm 0.09 a$ & $3.49 \pm 0.01 \mathrm{~cd}$ & $24.2 \pm 0.00 \mathrm{e}$ \\
\hline & Citric acid & $1.72 \pm 0.08^{\mathrm{abc}}$ & $3.19 \pm 0.01 \mathrm{~g}$ & $23 \pm 0.00 \mathrm{~h}$ \\
\hline & *LEO & $1.30 \pm 0.04^{\text {bcd }}$ & $3.98 \pm 0.00 \mathrm{a}$ & $24.1 \pm 0.12 \mathrm{ef}$ \\
\hline \multirow{4}{*}{$\begin{array}{l}98-99^{\circ} \mathrm{C} / 10 \\
\min \end{array}$} & Control & $1.33 \pm 0.35^{\text {bcd }}$ & $3.67 \pm 0.01 \mathrm{~b}$ & $24 \pm 0.12 \mathrm{ef}$ \\
\hline & Lemon juice & $1.75 \pm 0.69 \mathrm{ab}$ & $3.62 \pm 0.01 \mathrm{~b}$ & $25 \pm 0.00 \mathrm{~d}$ \\
\hline & Citric acid & $1.85 \pm 0.05 \mathrm{ab}$ & $3.4 \pm 0.02 \mathrm{e}$ & $23.9 \pm 0.00 \mathrm{f}$ \\
\hline & LEO & $1.05 \pm 0.09 \mathrm{~cd}$ & $3.95 \pm 0.04 \mathrm{a}$ & $25.1 \pm 0.00 \mathrm{~d}$ \\
\hline \multirow{4}{*}{$\begin{array}{l}98-99^{\circ} \mathrm{C} / 5 \\
\min \end{array}$} & Control & $1.43 \pm 0.02^{\text {bcd }}$ & $3.48 \pm 0.02 \mathrm{~cd}$ & $26 \pm 0.12 c$ \\
\hline & Lemon juice & $1.50 \pm 0.07^{\text {bcd }}$ & $3.46 \pm 0.02 \mathrm{~d}$ & $27.7 \pm 0.12 b$ \\
\hline & Citric acid & $1.90 \pm 0.08 \mathrm{ab}$ & $3.34 \pm 0.03 \mathrm{f}$ & $28 \pm 0.12 \mathrm{a}$ \\
\hline & LEO & $1.62 \pm 0.07^{\text {abcd }}$ & $3.53 \pm 0.01 \mathrm{c}$ & $25.2 \pm 0.12 \mathrm{~d}$ \\
\hline
\end{tabular}

*LEO: Lemongrass essential oil; Means followed by the same letter in a column are not significantly different (Tukey's test. $\mathrm{P}<0.05$ )

\section{Hygienic quality of canned mangoes}

Of the 32 samples analyzed, 25 samples contained no germ (AMB) and 7 samples had a total number of germs of less than $40 \mathrm{CFU} / \mathrm{g}$ each. Interestingly, none of the samples contained detectable levels of coliforms $(<10 \mathrm{CFU} / \mathrm{g})$ or yeasts and moulds $(<10 \mathrm{CFU} / \mathrm{g})$.

\section{Sensorial attributes and acceptability of canned mangoes} The sensorial attributes of canned mango according to taster's responses are:

-the control sample (without any preservative) had an acceptable appearance $(77.8 \%)$ of the tasters, a good flavor $(66.7 \%)$, intact pieces (75\%) and moderately non-clear syrup (66.7\%);

-the canned mango using citric acid as a preservative had an acceptable appearance (88.9\%), a good flavor (77.8\%), intact pieces (77.8\%) and moderately non-clear syrup (75\%);

-the canned mango using LEO as a preservative had an acceptable appearance $(77.8 \%)$, a good aroma $(77.8 \%)$, intact pieces $(66.70 \%)$ and a non-clear syrup (44.4\%);

-the canned mango using lemon juice had a poor appearance $(55.6 \%)$, a good flavor $(66.7 \%)$, intact pieces $(55.6 \%)$, and clear syrup $(55.6 \%)$.

Concerning the acceptability of the canned mangoes according to the preservatives, $88.3 \%$ of panelists found that the canned mango containing citric acid was pleasant. This product has beenfollowed by canned mango containing LEO which was judged pleasant by $70.6 \%$ of panelists. The control sample (canned mango without preservative) was judged pleasant by $67.6 \%$ of panelists. Whereas the canned mango containing lemon juice was judged pleasant by $64.7 \%$ of panelists. For the pasteurization time, canned mango threaded for 10 min was judged pleasant by $100 \%$ of panelists. Regarding the acceptability according the mango cultivars, $83.3 \%$ of panelists found canned mangoes processing with Kent cultivar were pleasant, $82.6 \%$ of panelists found canned mangoes processing with Lippens culti- 
Citation: Sawadogo-Lingani, H., et al. Processing of Canned Mango using Natural Preservatives: Effect on the Physicochemical Characteristics and Hygienic Quality. (2018) Int J Food Nutr Sci 5(1): 38- 46.

var were pleasant and 62.5 of panelists found canned mangoes processing with Keitt cultivar were pleasant.

\section{Discussion}

Canned mangoes were produced from three mangoes cultivars in Burkina Faso by using natural preservatives and processing adapted to small and medium enterprise level. Hygienic, nutritional and sensorial qualities of the final products were evaluated. Used preservatives did not influence the dry matter, total sugars and total soluble solids of canned mangoes. Concerning the influence of the heat treatment on dry matter, total sugar and total soluble solids, results showed different effects depending on the mango cultivar. As pasteurization for a long time (15 min) favored the increase in dry matter content of the Lippens and Kent canned mangoes, it decreased for the Keitt canned mangoes. The results obtained with the Lippens and Kent cultivars are in accordance with those of Thai et al. (2010 ${ }^{[26]}$ and those of Jiokap Nono et al. $(2001)^{[27]}$.

The overall results of the $\mathrm{pH}$ of canned mangoes are similar to those of Agassounon et al. (2007) ${ }^{[14]}$ who found that $\mathrm{pH}$ values ranged from 3.0 to 4.1 in canned mangoes from Kent cultivar. The lowest $\mathrm{pH}$ value was observed with canned mangoes containing citric acid. This tricarboxylic acid is an acidifying agent used in in food and beverage industries ${ }^{[28]}$. In contrast the highest $\mathrm{pH}$ values were obtained with control canned mangoes and canned mangoes containing $t$ lemongrass essential oil depending on the cultivar. Concerning the impact of pasteurization, the highest $\mathrm{pH}$ was observed in canned mango pasteurized for 10 to $15 \mathrm{~min}$. The increase in $\mathrm{pH}$ as a function of the duration of the heat treatment was also reported by Thai et al. $(2010)^{[26]}$.

Results show that temperature increased the content of $\beta$-carotene because the longer was the exposure (10 and $15 \mathrm{~min}$ ); the higher was $\beta$-carotene content. These data are in line with those of Djioua et al. (2009) ${ }^{[29]}$ who observed a slight increase of $\beta$-carotene and carotenoids, by performing heat treatment on mango slices. Similar results were also obtained on the levels of lycopene from tomato ${ }^{[30]}$. This may be justified by the fact that heat treatment can induce cell membrane disruption and enhance chemical extractability of carotenoids (Kidmose et al. 2002).

The tested conservatives citric acid, lemongrass essential oil and lemon juice better preserve $\beta$-carotene of mango pulp for canning. Similar results were observed by Sawadogo-Lingani (1993) ${ }^{[30]}$ while drying mango with chemical preservatives using sodium metabisulphite and sulfur dioxide. Nevertheless, it is important to stress that there is a significant difference between $\beta$-carotene content of canned mango depending on cultivar. The highest $\beta$-carotene content was obtained with the Kent cultivar using lemon juice or lemongrass essential oil.

As for the effect of canning process on the nutritional and physicochemical characteristics of fresh mango pulp, the process brings into contact fresh mango pieces and sugar syrup with a Brix degree higher than that of mango. After pasteurization, cooling and storage at room temperature for seven to fifteen days, equilibrium is established according to the principles of the osmosis between sugar concentrations in mango pieces and that of the sucrose syrup ${ }^{[14,15]}$. The mango pieces incorporate by endosmosis the sucrose which allows an increase in the total carbohydrate contents and dry matter as well. Thus canned man- goes are more energetic compared to fresh mango.

For the observed decrease of ash content, in principle, ashes are not destroyed by heat but when canning is processed with a liquid, soluble micronutrients are in osmosis equilibrium between mango pieces and juice ${ }^{[31,32]}$. The observed destruction of microorganisms is due to the combined action of heat preservatives and high sugar content ${ }^{[31,14]}$. Canned mangoes therefore have better microbiological quality compared with the fresh $\operatorname{mango}^{[33-35]}$.

\section{Conclusion}

The technological process developed allowed to obtain canned mangoes with a good hygienic quality. The results showed that Kent, Lippens and Keitt cultivars are suitable for canning. The process increased some nutrients and decreased others. Citric acid and lemnograss essential oil better preserved $\beta$-carotene. Sensorial analysis indicated that consumers preferred canned mangoes with preservatives. The developed process using simple equipment can be easily transfer to SMIs working on fruits and vegetables processing. The visible fallout is the possibility of the production of canned mango using natural preservatives to contribute to the diversification of mango products in the SMEs/SMIs in order to increase food and nutrition security in mango producing countries in Africa.

Acknowledgement: This study was supported by World Bank though the West African Agricultural Productivity Program (WAAPP) and the Centre National de Spécialisation des Fruits et Légumes (CNS-FL). We are also grateful to the technicians (Mamounata Congo/Tiendrebéogo, Adama Paré; Inoussa Salambéré, Adama Lodoun, Souleymane Zongo and Daouda Fofana) of DTA/IRSAT/CNRST for their assistance.

Conflict of Interest: No conflict of interest.

\section{References}

1. PAFASP, Promotion of the mango sector: PAFASP at the heart of the action. (2015).

Pubmed | Crossref |Others

2. DGPER, Situation de référence des principales filières agricoles aux du Burkina Faso. (2011) Report of the Ministry of Agriculture and Food Security:208.

Pubmed |Crossref $\mid$ Others

3. Arnoldus, M. Floris, V.D. Improving the performance of the processed mango products sector in Burkina Faso and Mali. (2009) PCDA/PAFASP, Study for the World Bank $116 \mathrm{p}$.

Pubmed $\mid$ Crossref $\mid$ Others

4. Campbell, C.W. Mango and other tropical fruits committee report. (1983) Florida Agr. In the 80s. Univ. Florida. Gainesville, Fla. 84(5):320-323.

Pubmed $\mid$ Crossref $\mid$ Others

5. CBI, Characteristics produced for fresh mangoes. (2014) CBI Market Information Database. 9p.

Pubmed |Crossref $\mid$ Others

6. Codex. Norme codex pour les mangues en conserve. (1987) 
Codex stan 159, 10p.

Pubmed $\mid$ Crossref $\mid$ Others

7. Couvert, O. Taking into account the influence of $\mathrm{pH}$ in the optimization of heat treatments. (2002) Thesis of the University of Western Brittany: 192.

Pubmed | Crossref | Others

8. Bourrier, T. Intolerances and allergies to dyes and additives Intolerance and allergy to dyes and additives. (2006) Elsevier 46(2006): 68-79.

Pubmed |Crossref | Others

9. Romeo, F.V., Luca, D.S., Piscopo, A., et al. Effect of Some Essential Oils as Natural Food Preservatives on Commercial Grated Carrots. (2010) Journal of Essential Oil Research 22(3): 283-287.

Pubmed | Crossref $\mid$ Others

10. Hyldgaard, M., Mygind, T., Meyer, R.L. Essential oils in food preservation: mode of action, synergies, and interactions with food matrix components. (2012) Frontiers in Microbiology 3(12): 1-24.

Pubmed | Crossref | Others

11. Witkowska A.M., Hickey, D.K., Wilkinson M. G. Effect of Variation in Food Components and Composition on the Antimicrobial Activity of Oregano and Clove Essential Oils in Broth and in a Reformulated Reduced Salt Vegetable Soup Product. (2014) Journal of Food Research 3(6): 92 106.

Pubmed | Crossref $\mid$ Others

12. Bassolé, I.H., Lamien-Meda, A. Bayala, B., et al. Chemical composition and antimicrobial activity of Cymbopogon citratus and Cymbopogon giganteus essential oils alone and in combination. (2011) Phytomedicine 18(12): 1070 1074.

Pubmed | Crossref | Others

13. Helander, I.M., Alakomi, H.L., Latva-Kala, K., et al. Characterization of the Action of Selected Essential Oil Components on Gram-Negative Bacteria 46 (9): 3590-3595 Pubmed | Crossref | Others

14. Agassounon D.T. M., Toukourou F., Gandonou C., et al. Manganese conservation tests with high moisture content by barrier technology. (2007) Rev CAMES 5: 53-58. Pubmed | Crossref $\mid$ Others

15. BIT. Small-scale fruit conservation, technical file. (1990) Technology Series 14: 0258-0462. Pubmed | Crossref $\mid$ Others

16. Norme Française V 03-707. Cereals and cereal products. Determination of the water content. (2000) Practical reference method $8 \mathrm{p}$. Pubmed $\mid$ Crossref $\mid$ Others

17. Montreuil, J., Spik, G. Microdosing of carbohydrates. I / Colorimetric method for the determination of total carbohydrates. (1969) Monographe du labo-chimie-biol. Fac. Sc. Lille (France).

Pubmed $\mid$ Crossref $\mid$ Others

18. Norme Française V 05-101. Determination of the titratable acidity of fruits and vegetables (1986). Pubmed $\mid$ Crossref $\mid$ Others

19. Some I., Zagre M., Kafando P. et al. Validation of a HPLC carotenoid assay method: application to the determination of carotenoid content in ten varieties of sweet potato (Ipomea batata). (2004) C. R. Chimie, 7: 1063-1071.

Pubmed | Crossref $\mid$ Others

20. Norme Française EN ISO 6887-1 Microbiology of food and animal feeding stuffs: preparation of test samples, initial suspension and decimal dilutions for microbiological examination - Part 1: (1999) General rules for the preparation of the suspension and decimal dilutions.

Pubmed $\mid$ Crossref $\mid$ Others

21. Norme Internationale ISO 4832 (2006). Microbiology of Foods - Horizontal Method for Counting Coliforms - Colony Count Method. 6p.

Pubmed | Crossref $\mid$ Others

22. Norme Française ISO 7954. General guidelines for the enumeration of yeasts and molds, colony counting techniques at $25^{\circ} \mathrm{C}$. (1988) $4 \mathrm{p}$.

Pubmed | Crossref $\mid$ Others

23. Norme Internationale ISO 11035. Sensory analysis - Research and selection of descriptors for the development of a sensory profile by multidimensional approach. (1994) Première édition $(\mathrm{F})$.

Pubmed |Crossref $\mid$ Others

24. Cochran WG and Cox GM. Experimental design. (1957) ISBN 10: $04711620352^{\text {nd }}$ edition, New York: Willey.

Pubmed | Crossref | Others

25. Rogeaux, M. Rapid Sensory Profiling Techniques. (2015). In book 345-362.

Pubmed $\mid$ Crossref $\mid$ Others

26. Thai T.H., Do M.H., G. Self, et al. Technical paper Effects of hot air treatment on postharvest qualityof "Cat Hoa loc" mangoes. (2010) Fruits 65: 237-244.

Pubmed | Crossref $\mid$ Others

27. Jiokap Nono, Y., Bertin, G., Raoult-Wack, A. et al. Behavior of certain tropical fruits treated by dehydration impregnation by immersion in a solution of sucrose. (2001) Fruit 56: 75-83.

Pubmed | Crossref $\mid$ Others

28. NBF 01-020. (2009) Burkinabé standard for canned mangoes. $9 \mathrm{p}$

Pubmed | Crossref $\mid$ Others

29. Djioua T., Charles F., Lopez-Lauri F., et al. Improving the storage of minimally processed mangoes (Mangifera indica L.) by hot water treatments. (2009) Postharvest Biology and Technology 52: 221-226.

Pubmed | Crossref $\mid$ Others

30. Amiot-Carlin, M.J., Caillavet, F., Causse, M., et al. Fruits and vegetables in the diet: Issues and determinants of consumption. (2007) Expertise scientifique collective, synthèse du rapport. INRA (France), 80.

Pubmed | Crossref $\mid$ Others

31. Sawadogo-Lingani, H. Technological valorization of Amélie mango variety from Burkina Faso: control of physicochemical parameters for better stabilization of transformation products. (1993) 164.

Pubmed | Crossref $\mid$ Others

32. Jiokap Nono.Y., Bertin, G., Raoult-Wack, A. et al. Dehydration-impregnation by immersion of mango slices (Mangifera indica): influence of the temperature and the concen- 
tration of the solution on the kinetics of certain elements of the fruit. (2001) Fruit 56(3): 169-177.

Pubmed |Crossref| Others

33. Craft, N., Soares J.J. Relative solubility, stability, and absorptivity of lutein and $\beta$-carotene in organic solvents. (1992) J Agric Food Chem 40(3): 431-434.

Pubmed | Crossref| Others

34. CEDEAO. Strategic Orientation Document for the Mango Value Chain in the Economic Community of West African States. (2011) Rapport CEDEAO: 146.

Pubmed | Crossref|Others

35. Fruits. Regional control of fruit flies in sub-Saharan Africa. (2010) COLEACP/CIRAD. Information letter.

Pubmed $\mid$ Crossref $\mid$ Others

Submit your manuscript to Ommega Publishers and we will help you at every step:

- We accept pre-submission inquiries

- Our selector tool helps you to find the most relevant journal

- We provide round the clock customer support

- Convenient online submission

- Thorough peer review

- Inclusion in all major indexing services

- Maximum visibility for your research

Submit your manuscript at

ommega Publishers 